\title{
Estimation of sediment production in oil palm expansion areas in the Amazon
}

\author{
Antonio K. L. Silva ${ }^{1}$, Adriano M. L. de Sousa ${ }^{2}$, Joyse T. S. dos Santos ${ }^{3}$, \\ João M. Villela ${ }^{4}$, Lucieta G. Martorano ${ }^{5} \&$ Silvio Crestana ${ }^{6}$
}

${ }^{1}$ Universidade Federal Rural da Amazônia/Campus Capanema/Colegiado de Engenharia Ambiental e Energias Renováveis. Capanema, PA. E-mail: antonio.leal@ufra.edu.br (Corresponding author) - ORCID: 0000-0001-6047-1419

${ }^{2}$ Universidade Federal Rural da Amazônia/Instituto Socioambiental e dos Recursos Hídricos. Belém, PA. E-mail: adriano.souza@ufra.edu.br - ORCID: 0000-0002-2809-5318

${ }^{3}$ Universidade Federal do Pará/Programa de Pós-graduação de Ciências Ambientais. Belém, PA. E-mail: joysetaty@hotmail.com - ORCID: 0000-00017292-8738

${ }^{4}$ Universidade de São Paulo/Pós-Graduação em Ciências da Engenharia Ambiental/Embrapa Instrumentação. São Carlos, SP. E-mail: jomarvile@hotmail.com - ORCID: 0000-0002-4093-7231

${ }^{5}$ Embrapa Amazônia Oriental/Núcleo de Apoio à Pesquisa e Transferência de Tecnologia. Santarém, PA. E-mail: lucieta.martorano@embrapa.br - ORCID: 0000-0003-3893-3781

${ }^{6}$ Embrapa Instrumentação. São Carlos, SP. E-mail: silvio.crestana@embrapa.br - ORCID: 0000-0002-1706-1024

\section{Key words:}

SWAT

ungauged river basin

secondary forest

northeastern Pará

\begin{abstract}
A B S T R A C T
Currently, an activity that has become strategic at a national level is the cultivation of oil palm (Elaeis guineensis) in the northeast region of the Pará State, in eastern Brazilian Amazon. However, the impacts of this crop expansion on the hydro-sedimentological cycle are still unknown. Therefore, this study estimated the impacts of oil palm crop expansion on sediment production in a sub-basin under consolidated use of this crop. The Soil and Water Assessment Tool (SWAT) model was applied in the Mariquita sub-basin, calibrated by the flow regionalization technique, using data measured in the field with a current meter. Simulation results indicated an increase in sediment production between the years 2008 and 2013, which can be attributed to the large reduction of areas of secondary vegetation that were replaced by pasture, oil palm and general agriculture. Oil palm areas had a lower average monthly sediment yield in the rainiest period in all simulated years, compared with areas of general agriculture and pasture.
\end{abstract}

\section{Palavras-chave: \\ SWAT}

bacia hidrográfica não monitorada vegetação secundária nordeste do estado do Pará

\section{Estimativa da produção de sedimentos em áreas de expansão da palma de óleo na Amazônia}

\begin{abstract}
R E S U M O
Atualmente, uma atividade que se tornou estratégica a nível nacional é o cultivo da palma de óleo (Elaeis guineensis) na região nordeste do estado do Pará, na Amazônia oriental brasileira. Entretanto, se conhece pouco ainda dos impactos da expansão dessa cultura sobre o ciclo hidrossedimentológico. Por isso, este trabalho estimou os impactos da expansão da cultura da palma de óleo sobre produção de sedimentos em uma sub-bacia de uso consolidado dessa cultura. Aplicou-se o modelo hidrossedimentológico Soil and Water Assessment Tool (SWAT) na Sub-Bacia do Rio Mariquita, PA, calibrando o modelo utilizando a técnica de regionalização de vazão, a partir de dados medidos em campo com o molinete hidrométrico. Os resultados das simulações indicaram um aumento da produção de sedimentos entre os anos de 2008 e 2013, podendo ser atribuído à grande redução de áreas de vegetação secundária que foram substituídas pelos cultivos de pastagem, palma de óleo e agricultura geral. As áreas de palma de óleo tiveram uma produção média mensal de sedimentos menor no período mais chuvoso em todos os anos simulados, se comparadas às áreas de agricultura geral e pastagem.
\end{abstract}




\section{INTRODUCTION}

Brazilian Amazon region, especially northeastern Pará state, has undergone an accelerated economic development (Becker, 2005), causing a series of socioeconomic and environmental impacts due to the lack of territorial planning. Among these impacts, alterations in surface runoff regime and intensification of erosive processes stand out (Yang et al., 2009), leading to reduction of soil fertility, formation of gullies, contamination of water resources and silting of rivers and reservoirs (Filizola et al., 2011).

Currently, oil palm (Elaeis guineensis) cultivation became strategic on a national level for the energy and food production market (Ramalho Filho, 2010). With excellent biophysical, socioeconomic and political conditions, the northeastern region of the Pará state has faced a large expansion of this crop, motivating some studies on the possible environmental impacts. These studies particularly include those related to carbon rates in the soil (Guillaume et al., 2016), planting in deforested or degraded areas (Carvalho et al., 2015), as well as its influence on the dynamics of soil use and occupation (Wicke et al., 2011). However, there is a demand for studies evaluating the impacts of crop expansion on the hydro-sedimentological regime on a water basin scale.

The hydro-sedimentological model SWAT (Soil and Water Assessment Tool) allows to evaluate the impact of different soil uses on surface runoff and sediment production (Zhang et al., 2009; Arnold et al., 2012). This tool has been employed to study the influence of the expansion of oil palm areas on water and sediment yields in Malaysia (Alansi et al., 2009) and Thailand (Babel et al., 2011), presenting important data for the planning of soil use and cover in water basins.

Therefore, the SWAT model was applied to an ungauged sub-basin of the Mariquita River, located in the eastern Brazilian Amazon, to evaluate the impacts of oil palm expansion on sediment production.

\section{Material AND Methods}

The study was carried out in sub-basin of the Mariquita River (MRSB), with area of $159.94 \mathrm{~km}^{2}$, tributary of the AcaráMirim river (Figure 1), located in the Northeast mesoregion of the Pará state, municipality of Tomé-Açu $\left(48^{\circ} 22^{\prime} 38^{\prime \prime} \mathrm{W}, 2^{\circ} 22^{\prime}\right.$ $41^{\prime \prime} \mathrm{S}$ and $\left.48^{\circ} 30^{\prime} 42^{\prime \prime} \mathrm{W}, 2^{\circ} 34^{\prime} 08^{\prime \prime} \mathrm{S}\right)$. The climate of the region is classified as Am, according to Köppen's classification, with mean temperature of $27.9^{\circ} \mathrm{C}$, mean annual rainfall of $2500 \mathrm{~mm}$ and relative air humidity of $80 \%$, and the area has predominance of dystrophic Yellow Latosol and declivity from 0 to $13 \%$.

The SWAT model was used to evaluate the impacts on the hydro-sedimentological cycle caused by the changes in soil use and cover, occurred in the years 2008 and 2013. The map of soil use and cover for 2013 was elaborated according to the TerraClass project for the year 2008 (INPE, 2014), using LandSat 8 satellite images. Table 1 and Figure 2 show the data of soil use and cover in the MRSB, in which the year 2008 represents the context before oil palm expansion, and 2013, the context after its expansion.

The Digital Elevation Model was generated from SRTM (Shuttle Radar Topography Mission) images with 90-m resolution. Pedological information on the number of soil layers, organic carbon, sand, silt, clay and rock of the soil profiles, obtained from ZEE-PA (2010) and profiles opened for soil physical and chemical analysis in the MRSB, was used to estimate all the other soil parameters necessary in the SWAT model through pedotransfer functions (Saxton \& Rawls, 2006). Some parameters of the uses were adjusted to the characteristics of the region, such as Manning roughness coefficient (OV_N); maximum height of tree canopy (CHTMX), maximum leaf area index (BLAI) and maximum root depth (RDMX). Climate data of rainfall $(\mathrm{mm})$ from 2003 to 2014 were provided by the National Water Agency (ANA) and the other climate data were provided by the National Institute of Meteorology (INMET).

Table 1. Areas for each class of soil use and cover in 2008 and 2013 in the MRSB

\begin{tabular}{|c|c|c|c|c|}
\hline \multirow{3}{*}{ Use and cover } & \multicolumn{4}{|c|}{ Area } \\
\hline & \multicolumn{2}{|c|}{2008} & \multicolumn{2}{|c|}{2013} \\
\hline & (ha) & $(\%)$ & (ha) & $(\%)$ \\
\hline General agriculture & 407.0 & 2.55 & 916.4 & 5.73 \\
\hline Oil palm & --- & --- & 2316.5 & 14.48 \\
\hline Pasture & 5455.9 & 34.11 & 4222.7 & 26.40 \\
\hline Forest remnants & 4134.2 & 25.85 & 3883.0 & 24.28 \\
\hline Secondary vegetation & 5967.6 & 37.31 & 4634.3 & 28.98 \\
\hline Water* & 29.3 & 0.18 & 2.7 & 0.02 \\
\hline Urban area & --- & --- & 18.6 & 0.12 \\
\hline Total & 15993.9 & 100.0 & 15993.9 & 100.00 \\
\hline
\end{tabular}

*Area variation in the class "Water" may be linked to classifier interpretation and LandSat image quality

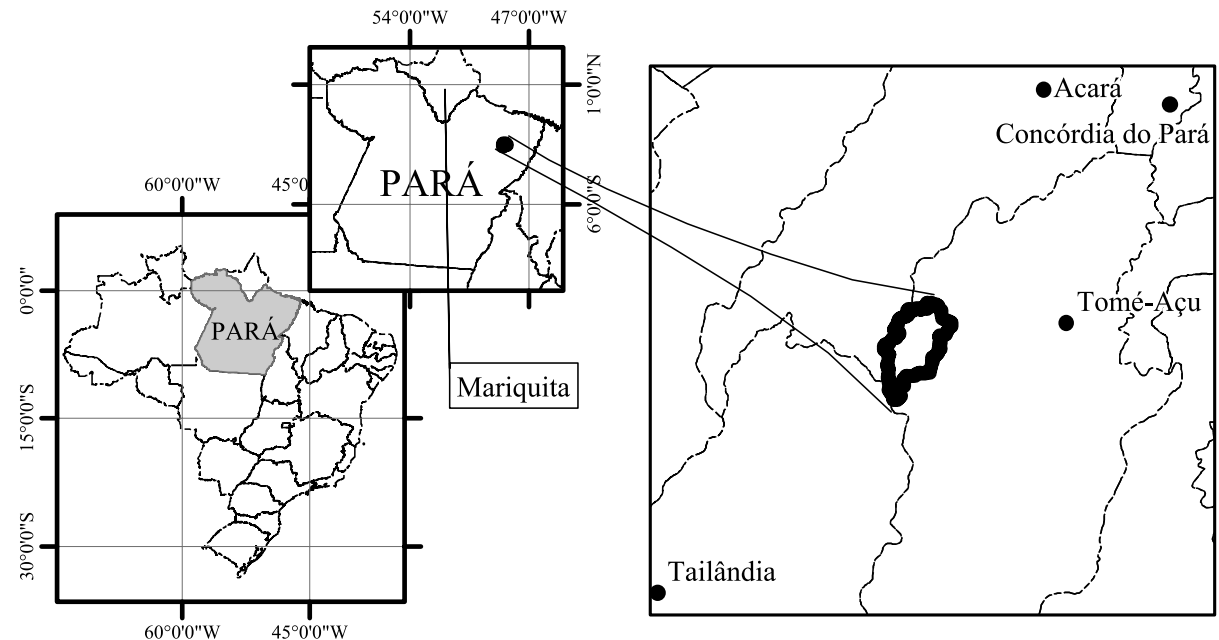

Figure 1. Location map of the MRSB

\section{Legend}
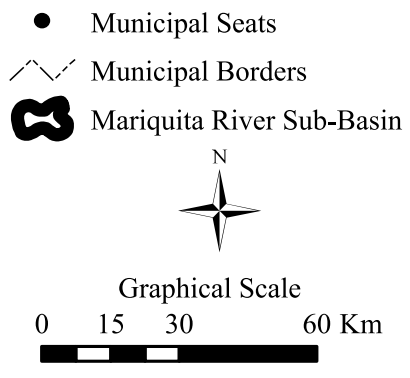

Numerical Scale: 1:2000.000

Projection system: UTM

Datum: South American 1969 Zone: 22 South 
A.

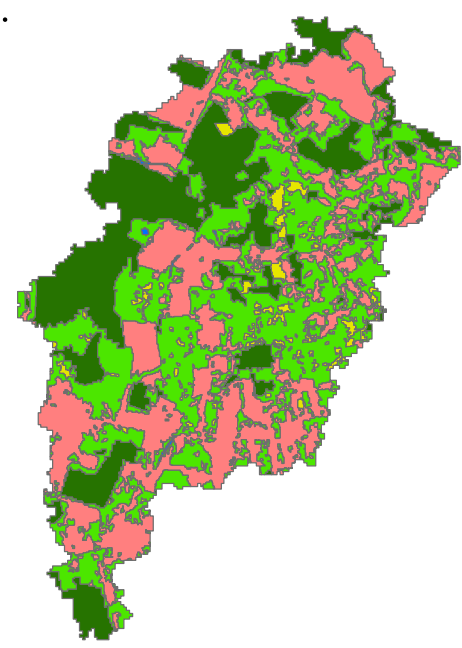

B.

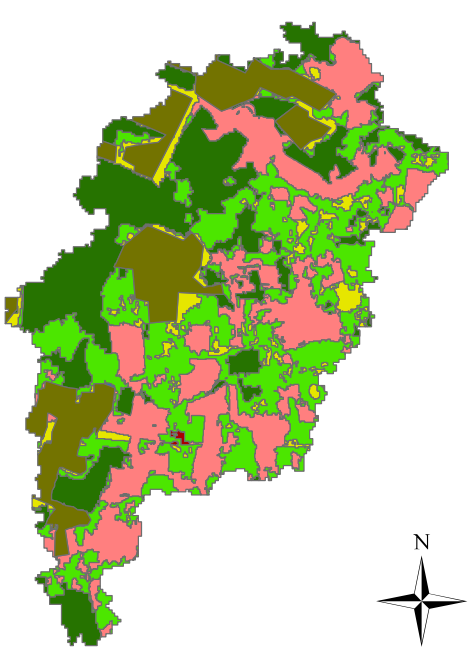

Legend

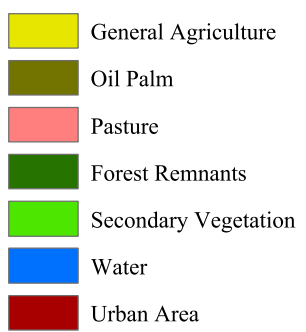

Graphical Scale

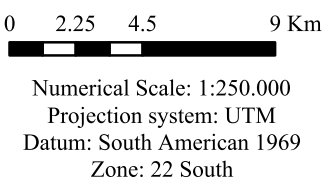

Figure 2. Maps of soil use and cover in the years 2008 (A) and 2013 (B) for the MRSB

The MRSB was divided into 11 sub-basins, 62 units of hydrological response and 4 classes of declivity: 0-3, $3-13,13-20$, and from $20 \%$ on. For surface runoff and evapotranspiration, the Curve Number $(\mathrm{CN})$ method of the Soil Conservation Service and the Priestley-Taylor equation were respectively used. Three years were used for training (2003 to 2005), five years for calibration (2006 to 2010) automatically performed using the SWAT-CUP software (Abbaspour, 2014) and four years for validation (2011 to 2014).

The flow data relative to the period from 2006 to 2014, used in the simulations, were obtained by the flow regionalization technique, by applying non-linear regression equations (Tucci, 2002) and using as independent variables the basin drainage area $\left(\mathrm{km}^{2}\right)$ and mean rainfall $(\mathrm{mm})$ to estimate the long-term average monthly flow and average flow for each month of each year of the series from 2006 to 2014. Data from four fluviometric stations of ANA were used: two in the Guamá River Basin $\left(5005.1 \mathrm{~km}^{2}\right)$ and two in the Capim River Basin $\left(33384.3 \mathrm{~km}^{2}\right)$, also located in the northeastern region of the Pará state, under similar geophysiographic characteristics (Goswami et al., 2007).

To evaluate the synthetic series of flow generated by the regionalization and by the SWAT model, flow was measured at the end of the rainy period (May) and dry period (December) in 2014, using a current meter. The correctness of flow measurements was determined using the Nash-Sutcliffe coefficient (NSE) (Moriasi et al., 2007).

\section{Results AND Discussion}

Validation of regionalization through the test with the Nash-Sutcliffe coefficient (NSE) showed satisfactory results for the Badajós station (0.52) and very good for the stations Fazenda Maringá (0.89), Bom Jardim (0.83) and Vila Capoeira (0.98). After validation, the regionalization equation was applied to generate series from 2006 to 2014 for the MRSB. Statistical results demonstrate the adequacy of the method of calibration and validation regarding the regionalized monthly flow from 2006 to 2014 (NSE $=0.73$ ) and regarding the longterm regionalized average monthly flow (NSE $=0.93)$. In both analyses, the model showed good results (Moriasi et al., 2007).
An expressive modification occurred between 2008 and 2013 due to the expansion of oil palm (OILP), which changed from $0 \%$ in 2008 to $14 \%$ in 2013 . General agriculture areas increased by approximately $125 \%$, whereas pasture areas (PAST) decreased by $22.6 \%$ and secondary vegetation areas (FRSE_VS) decreased by $22.3 \%$. Areas of forest remnants (FRSE_RF) remained virtually unchanged (Table 1).

Sediment production rates in total amounts between 2008 and 2013 in the MRSB increased by about 16\%, changing from $41.1 \mathrm{t} \mathrm{ha}^{-1}$ year $^{-1}$ in 2008 to $47.7 \mathrm{t} \mathrm{ha}^{-1}$ year $^{-1}$ in 2013. Long-term average monthly accumulations (from 2006 to 2014) also demonstrated increase of sediment production in the MRSB from 2008 to 2013 during the rainy period, such as the production peak that occurred in March, $11.9 \mathrm{t} \mathrm{ha}^{-1}$ for 2008 and $14.2 \mathrm{t} \mathrm{ha}^{-1}$ for 2013. Increase in sediment production (Figure 3) results from the replacement of FRSE_VS areas $(\mathrm{CN}=50)$ by general agriculture areas $(\mathrm{AGRL})(\mathrm{CN}=69)$ and OILP areas $(\mathrm{CN}=59)$, increasing the average value of the Curve Number (CN), as well as increasing surface runoff and sediment production. Influence of $\mathrm{CN}$ on surface runoff and sediment production has been confirmed (Kim et al., 2010; Bonumá et al., 2015) and it is important to understand the impacts of agriculture on soil loss and water contamination (Chaubey et al., 2010).

Oil palm expansion occurs particularly in the sub-basins 3, 6 and 10, and the latter two showed large occupation of FRSE_RF and FRSE_VS in 2008 and in 2013, but OILP advanced over the areas of PAST and AGRL. Nevertheless, the replacement of PAST and AGRL areas by OILP does not negatively affect sediment production, only in 2013 for the sub-basin 3, since the OILP advances over the FRSE_VS areas, which lead to lower flow and lower sediment production. Due to the homogeneous declivity, soil use and cover was the main forcing of this distribution of surface runoff and sediment production (Figure 4). The results showed that AGRL areas, followed by PAST, were the ones that most produced sediments in the MRSB (Table 2) and the OILP areas showed lower sediment production compared with AGRL and PAST. Forest areas showed the lowest production rates.

The present study found an average annual sediment production lower than $7 \mathrm{t} \mathrm{ha}^{-1}$ year-1 $^{-1}$ (Figure 4), as also reported in the studies of Jesus (2009), in Argisols and with 
A.

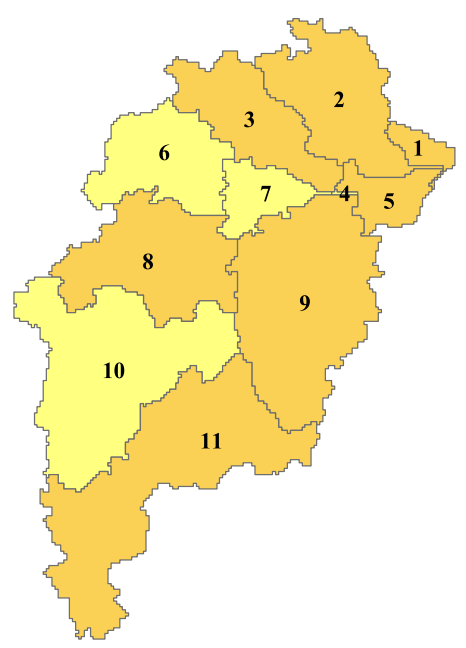

B.

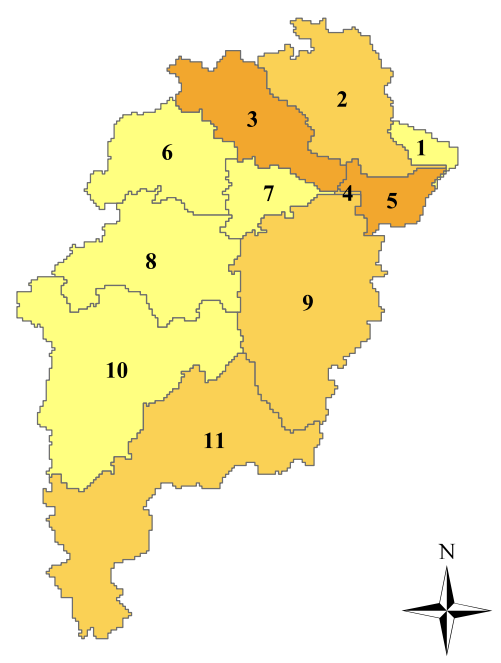

Legend

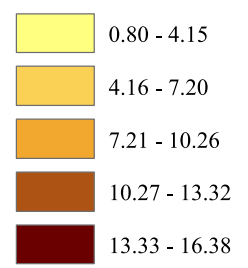

Geographic Scale

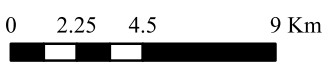

Numerical Scale: 1:250.000

Projection system: UTM

Datum: South American 1969

Zone: 22 South

Figure 3. Distribution of sediment production $\left(\mathrm{t} \mathrm{ha}^{-1}\right)$ in the MRSB for the years 2008 (A) and 2013 (B)

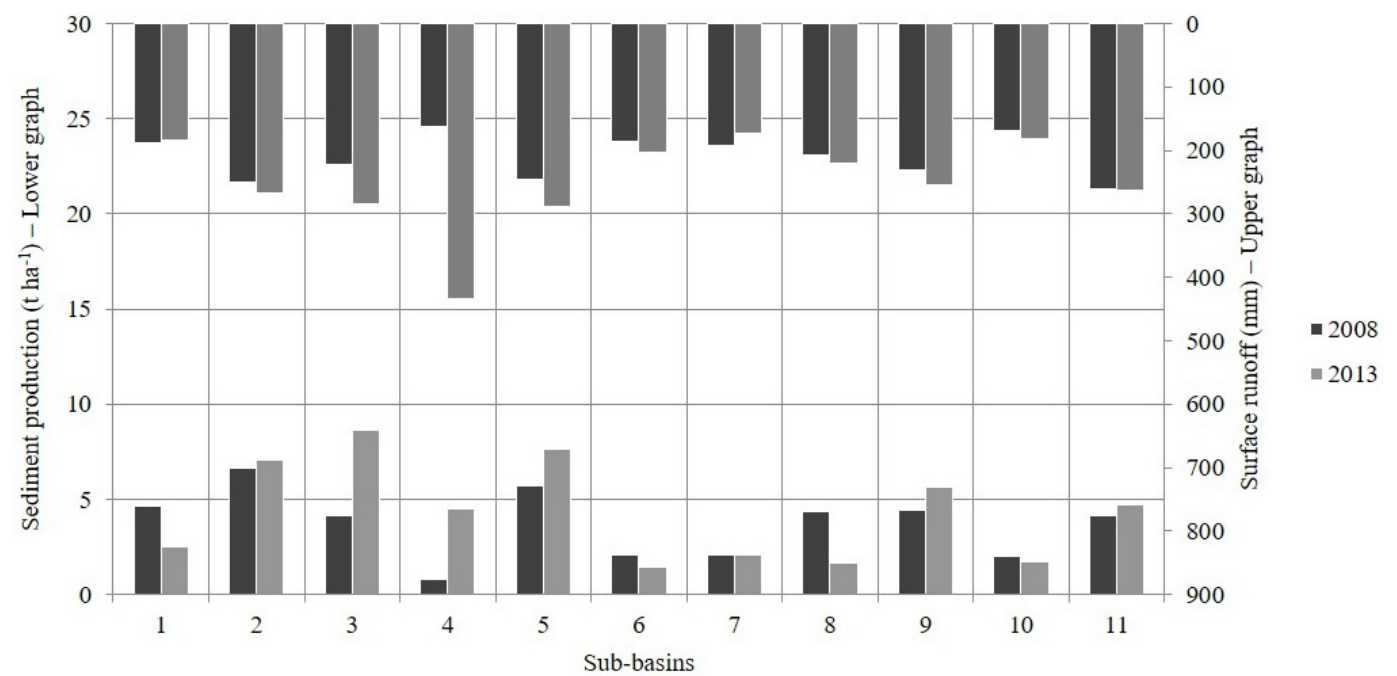

Figure 4. Surface runoff and sediment production in the 11 sub-basins of the MRSB

Table 2. Long-term monthly average and annual sum of sediment production relative to 12 months of the seasonal cycle and for the 6 rainiest months between the simulated years of 2006 and 2014 for the MRSB in both maps of soil use and cover.

\begin{tabular}{|c|c|c|c|c|}
\hline \multicolumn{5}{|c|}{ Sediment production in the Mariquita River Sub -basin $\left(\mathrm{t} \mathrm{ha}^{-1}\right)$} \\
\hline & \multicolumn{2}{|c|}{12 months } & \multicolumn{2}{|c|}{6 rainiest months } \\
\hline & Mean & Sum & Mean & Sum \\
\hline & \multicolumn{4}{|c|}{ Map of 2008} \\
\hline OILP & 0.054 & 0.650 & 0.099 & 0.594 \\
\hline AGRL & 0.891 & 10.690 & 1.512 & 9.070 \\
\hline PAST & 1.346 & 15.650 & 2.459 & 14.757 \\
\hline \multirow[t]{2}{*}{ FRSE } & 0.004 & 0.034 & 0.006 & 0.034 \\
\hline & \multicolumn{4}{|c|}{ Map of 2013} \\
\hline OILP & 0.169 & 2.030 & 0.306 & 1.835 \\
\hline AGRL & 1.037 & 12.060 & 1.705 & 10.232 \\
\hline PAST & 1.267 & 14.720 & 2.313 & 13.878 \\
\hline FRSE & 0.004 & 0.035 & 0.006 & 0.035 \\
\hline
\end{tabular}

fewer forest areas, and Santos et al. (2015), with predominance of Latosols and absence of forests, also conducted in the northeastern region of the Pará state. These results demonstrate that sediment production was much lower than the soil loss

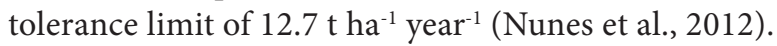

For oil palm, Babel et al. (2011) found that the scenario of oil palm expansion showed insignificant alteration in evapotranspiration and water yield, but observed an increase in nitrate supply, which is linked to the greater supply of nitrogen fertilizer. Conversely, Majid \& Rusli (2014) pointed to an increment in surface runoff when forest areas were replaced by rubber tree plantations and then by oil palm in the Muar River Basin (Malaysia). Thus, identifying that the change in soil use and cover has influenced the hydrosedimentological regime of the MRSB warns for the need to obtain more knowledge on the environmental impact of large agribusiness activities. Therefore, the modeling methodologies applied here combined with the sediment production data provide a range of important information for the region, especially with estimates of sediment production in oil palm areas. In addition, it was possible to identify the importance of secondary vegetation ecosystems for soil conservation and that oil palm plantations require monitoring and environmental management.

\section{Conclusions}

1. The results of sediment production estimates are important because they represent a range of information still inexistent for the region. 
2. The increment in sediment production in the MRSB is related to the expressive reduction in secondary vegetation and not specifically to oil palm expansion.

3. Oil palm areas showed lower average monthly sediment production in the rainiest period compared with areas of general agriculture and pasture.

\section{Acknowledgments}

To the PECUS Project and the Coordination for the Improvement of Higher Education Personnel (CAPES), for granting the doctoral scholarship; to the National Council for Scientific and Technological Development (CNPq), for granting the doctoral scholarship abroad through the Science Without Borders Program, at the TEXAS A\&M University; and to the ROBIN Project, for the funding to obtain soil data.

\section{Literature Cited}

Abbaspour, K. C. SWAT-CUP 2012: SWAT Calibration and uncertainty programs - A user manual. Eawag- DuebendorfSwitzerland: Departamento of Systems Analysis, Integrated Assessment and Modelling (SIAM); Swiss Federal Institute of Aquatic Science and Technology, 2014. 100p.

Alansi, A. W.; Amin, M. S. M.; Halim, G. A.; Shafri, H. Z. M.; Aimrun, W. Validation of SWAT model for stream flow simulation and forecasting in Upper Bernam humid tropical river basin, Malaysia. Hydrology and Earth System Sciences Discussions, v.6, p.75817609, 2009. https://doi.org/10.5194/hessd-6-7581-2009

Arnold, J. G.; Moriasi, D. N.; Gassman, P. W.; Abbaspour, K. C.; White, M. J.; Srinivasan, R.; Santhi, C.; Harmel, R. D.; Griensven, A. van; Liew, M. W. van; Kannan, N.; Jha, M. K. SWAT: Model use, calibration, and validation. Transactions of the ASABE, v.55, p.1491-1508, 2012

Babel, M. S.; Shrestha, B.; Perret, S. R. Hydrological impact of biofuel production: A case study of the khlong phlo watershed in Thailand. Agricultural Water Management, v.101, p.8-26, 2011. https://doi.org/10.1016/j.agwat.2011.08.019

Becker, B. K. Geopolítica da Amazônia. Estudos Avançados, v.19, p.71-86, 2005. https://doi.org/10.1590/S0103-40142005000100005

Bonumá, N. B.; Reichert, J. M.; Rodrigues, M. F.; Monteiro, J. A. F.; Arnold, J. G.; Srinivasan, R. Modeling surface hydrology, erosion, nutrient transport, and future scenarios with the ecohydrological SWAT model in Brazilian watersheds and river easins. Tópicos em Ciência do Solo, v.9, p.241-290, 2015.

Carvalho, C. M. de; Silveira, S.; Rovere, E. L. la; Iwama, A. Y. Deforested and degraded land available for the expansion of palm oil for biodiesel in the state of Pará in the Brazilian Amazon. Renewable and Sustainable Energy Reviews, v.44, p.867-876, 2015. https://doi.org/10.1016/j.rser.2015.01.026

Chaubey, I.; Chiang, L.; Gitau, M. W.; Mohamed, S. Effectiveness of best management practices in improving water quality in a pasture-dominated watershed. Journal of Soil and Water Conservation, v.65, p.424-437, 2010. https://doi.org/10.2489/ jswc.65.6.424

Filizola, H. F.; Almeida Filho, G. S. de; Canil, K.; Souza, M. D. de; Gomes, M. A. F. Controle dos processos erosivos lineares, ravina e voçorocas, em área de solos arenosos. Jaguariúna: Embrapa Meio Ambiente, 2011. 7p. Circular Técnica, 22
Goswami, M.; O'Connor, K. M.; Bhattarai, K. P. Development of regionalisation procedures using a multi-model approach for flow simulation in an ungauged catchment. Journal of Hydrology, v.333, p.517-531, 2007. https://doi.org/10.1016/j.jhydrol.2006.09.018

Guillaume, T.; Holtkamp, A. M.; Damris, M., Brümmer, B.; Kuzyakov, Y. Soil degradation in oil palm and rubber plantations under land resource scarcity. Agriculture, Ecosystems and Environment, v.232, p.110-118, 2016. https://doi.org/10.1016/j.agee.2016.07.002

INPE - Instituto Nacional de Pesquisas Espaciais. Projeto TerraClass. 2014. Disponível em <http://www.inpe.br/cra/projetos_pesquisas/ terraclass2010.php $>$. Acessed on: Jun. 2014.

Jesus, A. A. S. de. Geoprocessamento aplicado ao mapeamento da estimativa de perda de solos por erosão laminar na bacia hidrográfica do rio Apeú (nordeste paraense) - Amazônia Oriental. Belém, PA: Universidade Federal Rural da Amazônia, 2009. 117p. Dissertação Mestrado

Kim, N. W.; Lee, J. W.; Lee, J.; Lee, J. E. SWAT application to estimate design runoff curve number for South Korean conditions. Hydrological Processes, v.24, p.2156-2170. 2010. https://doi. org/10.1002/hyp.7638

Majid, M. R.; Rusli, N. Hydrological impact of large scale conversion of rubber to oil palm plantation. In: International SWAT Conference, 2014, Pernambuco. Livro de Resumos... Pernambuco. 2014.

Moriasi, D. N.; Arnold, J. G.; Liew, M. W. van; Binger, R. L.; Harmel, R. D.; Veith, T. L. Model evaluation guidelines for systematic quantification of accuracy in watershed simulations. Transactions of the ASABE, v.50, p.885-900, 2007.

Nunes, J. G.; Campos, M. C. C.; Oliveira, F. P.; Nunes, J. C. Tolerância de perda de solo por erosão na região sul do Amazonas. Ambiência, v.8, p.859-868, 2012. https://doi.org/10.5777/ambiencia.2012.05.05

Ramalho Filho, A. Zoneamento agroecológico, produção e manejo da cultura de palma de óleo na Amazônia. Rio de Janeiro: Embrapa Solos, 2010. 216p.

Santos, D. B. O.; Blanco, C. J. C.; Pessoa, F. C. L. RUSLE para determinação da tolerância de perda de solo. Biota Amazônia, v.5, p.78-83, 2015. https://doi.org/10.18561/2179-5746/biotaamazonia. v5n4p78-83

Saxton, K. E.; Rawls, W. J. Soil water characteristic estimates by texture and organic matter for hydrologic solutions. Soil Science Society of Agronomy Journal, v.70, p.1569-1578, 2006. https://doi. org/10.2136/sssaj2005.0117

Tucci, C. E. M. Regionalização de Vazões. Porto Alegre: Editora da Universidade- UFRGS, 2002. 256p.

Wicke, B.; Sikkema, R.; Dornburg, V.; Faaij, A. Exploring land use changes and the role of palm oil production in Indonesia and Malaysia. Land Use Policy, v.28, p.193-206, 2011. https://doi. org/10.1016/j.landusepol.2010.06.001

Yang, Q; Meng, F.-R.; Zhao, Z; Chow, T. L.; Benoy, G; Rees, H. W.; Bourque, C. P.-A. Assessing the impacts of flow diversion terraces on stream water and sediment yields at a watershed level using SWAT model. Agriculture, Ecosystems \& Environment, v.132, p.23-31, 2009. https://doi.org/10.1016/j.agee.2009.02.012

Zhang, X.; Srinivasan, R.; Bosch, D. Calibration and uncertainty analysis of the SWAT model using Genetic Algorithms and Bayesian Model Averaging. Journal of Hydrology, v.374, p.307-317, 2009. https:// doi.org/10.1016/ j.jhydrol.2009.06.023.

ZEE-PA - Zoneamento Ecológico-Econômico da Zona Leste e Calha Norte do Estado do Pará. Diagnóstico do Meio Físico-Biótico. 1.ed. Belém: Pará Rural, 2010. 326p. 